Original article

\title{
Effect of hepatitis B virus (HBV) infection on the course of pregnancy and newborns' health status
}

\author{
Tadeusz Wojciech Łapiński', Julita Stepaniuk1, Krzysztof Tomasiewicz², Dariusz Lebensztejn³ ${ }^{3}$ Marek Kulikowski, \\ Robert Flisiak' \\ 'Department of Infectious Diseases and Hepatology, Medical University of Bialystok, Bialystok, Poland \\ 2Department of Infectious Diseases, Medical University of Lublin, Lublin, Poland \\ ${ }^{3}$ Department of Paediatrics, Gastroenterology and Children's Allergology, Medical University of Bialystok, Bialystok, Poland \\ ${ }^{4}$ Department of Perinatology, Medical University of Bialystok, Bialystok, Poland
}

\begin{abstract}
Introduction: The effect of chronic hepatitis B virus (HBV) infection on pregnancy is not clear. Hepatitis B virus infection of newborns in the case of natural delivery occurs in 70-90\% of cases. Risk factors of infection are the presence of serum $\mathrm{HBeAg}$ and HBV DNA level above $10^{7} \mathrm{IU} / \mathrm{ml}$. Active and passive prevention protect more than $95 \%$ of neonates born to mothers infected with HBV. The aim of the study was to determine the course of pregnancy in HBV-infected women, the mode of delivery, efficacy of prophylaxis against HBV infection in newborns, and health condition of newborns within the first years of life.

Material and methods: The course of 104 pregnancies in 69 women infected with HBV was monitored. Hepatitis B virus viral load was determined by PCR using the AmpliPre/COBAS TaqMan HBV system. Neonatal HBV infection and the health condition at birth and during the first year of life were analyzed.

Results: All included pregnant women were HBeAg negative. No clinically significant disorders were observed during pregnancy. Viral load measured in the third trimester did not exceed $10^{7} \mathrm{IU} / \mathrm{ml}$ in any pregnant woman. Only $5(8 \%)$ of them demonstrated levels above $10^{5} \mathrm{IU} / \mathrm{ml}$. Two women (1.9\%) experienced a miscarriage, which was considered as not associated with HBV infection. The majority (56\%) of pregnancies ended with spontaneous labor. Complete prevention against HBV was applied in 79\% of newborns. Hepatitis B virus infection was diagnosed in 3 children who received incomplete or no prophylaxis. Hepatitis B virus infection occurred in $3(2.9 \%)$ children born naturally, who did not receive proper prevention after delivery. The Apgar score in children born to mothers infected with HBV did not differ significantly from that in neonates born to healthy women from the same population. Allergic disorders developed in 17 children who underwent HBV prophylaxis.

Conclusions: Low viral load in pregnant women infected with HBV and the absence of HBeAg reduce the probability of infection of newborns. Proper prevention carried out after delivery seems to be the most important method to prevent $\mathrm{HBV}$ infection in newborns.
\end{abstract}

Key words: pregnancy, newborns, HBV infection.

\section{Address for correspondence}

Prof. Tadeusz Wojciech Łapiński, Department of Infectious Diseases and Hepatology, Medical University of Bialystok, 14 Żurawia St., 15-540 Bialystok, Poland, e-mail: twlapinski@gmail.com

\section{Introduction}

Prevalence of hepatitis B virus (HBV) infection among European pregnant women is estimated at approximately $1 \%$ [1]. The risk of fetal hepatitis B infection during pregnancy is minimal, whereas in the peri- natal period, particularly in the case of spontaneous labor, it reaches up to $70-90 \%$.

Hepatitis $\mathrm{B}$ e $(\mathrm{HBe})$ antigen positivity and $\mathrm{HBV}$ viral load exceeding $10^{7} \mathrm{IU} / \mathrm{ml}$ are predisposing risk factors for fetal infection [2]. Routine examinations assessing possible $\mathrm{HBV}$ infection are essential in all 
pregnant women. In the case of existing infection, the viral load should be determined for possible introduction of appropriate management to protect a newborn.

Combined active and passive prevention protects neonates born to $\mathrm{HBV}$ infected mothers in more than $95 \%$ of cases [3]. In $43 \%$ of breastfeeding HBV infected women the virus is present in mothers' milk but the viral level is so low that it does not endanger newborns [4]. Most European and American pediatrician and gynecological associations give no contraindications for breastfeeding by HBV-infected mothers [1]. Asian studies concerning the preventive use of nucleoside or nucleotide analogues in the third trimester of pregnancy demonstrated efficacy and safety of these drugs [5]. However, in accordance with the Food and Drug Administration (FDA) classification, all nucleotide and nucleoside analogues are classified as B or C class because the safety studies in pregnant women were not carried out in the USA or European countries.

The aim of the study was to determine the impact of HBV infection on pregnancy, efficacy of prophylaxis against HBV infection in newborns, and health condition of newborns within the first year of life.

\section{Material and methods}

The study was carried out in 69 women, aged 21-42 (mean 29) years, chronically infected with HBV, whose 104 pregnancies were analyzed. Two women were pregnant 4 times, 6 had 3 deliveries, 19 had 2, and 42 had a single delivery. Twin pregnancies occurred in 2 women and single pregnancies in 102 women. Mean time of HBV diagnosis was 4.5 years (from 1 year to 20 years). All pregnant women were HBeAg-negative. The presence of HBV DNA in blood sera (qualitative) was demonstrated in all pregnant women in the antenatal period. Quantitative HBV DNA in blood sera in the third trimester was determined in the course of 59 pregnancies. Prospective analysis involved 59 whereas retrospective analysis was carried out in 45 out of 104 pregnant women. All pregnant women who were assessed for HBV DNA in the $3^{\text {rd }}$ trimester of pregnancy (59/104) were included in the prospective analysis.

In 102 pregnant women no antiviral therapy was initiated before pregnancy.

Immediately prior to pregnancy, two women with elevated ALT and a HBV DNA viral load of $10^{5} \mathrm{IU} / \mathrm{ml}$ were treated for 3 months with lamivudine and pegylated interferon (PEG-IFN). Treatment was discontinued at the moment of pregnancy diagnosis $\left(6^{\text {th }}\right.$ week of pregnancy).

In all women in the first trimester $\mathrm{HBsAg}, \mathrm{HBeAg}$, and anti-HBe antibodies were analyzed in the sera us- ing enzyme immunoassay (EIA, ABBOTT, Germany) and a qualitative HBV DNA test providing sensitivity of $5 \mathrm{IU} / \mathrm{ml}$ and linearity of $15 \mathrm{IU} / \mathrm{ml}$.

Quantitative evaluation of HBV viral load in sera was performed in the third trimester of pregnancy in 49 women. The presence and level of HBV DNA were determined by means of the PCR method using the COBAS AmpliPre kits/COBAS TaqMan HBV Test, version 2.0 (ROCHE company) [1]. The sensitivity of the assay was $9 \mathrm{IU} / \mathrm{ml}$ and linearity was $20 \mathrm{IU} / \mathrm{ml}$.

Medical history and current health conditions were collected from all newborns. Data were obtained from the medical history documentation concerning newborns' conditions in the $5^{\text {th }}$ minute after the delivery according to the Apgar score, birth weight and the mode of the delivery. The presence of HBsAg in blood sera was determined 6 months after the delivery in 93 out of 103 children (90\%). Information concerning children's health conditions was obtained from mothers and the period of follow-up lasted from 1 year to 13 years (mean 5.4 years).

All participating women provided informed consent in accordance with the protocol approved by the Bioethical Committee of the Medical University of Bialystok.

The statistical analysis was carried out using the $\chi^{2}$ test; statistical significance was considered at $p<0.05$.

\section{Results}

Pregnant women had no history of serious diseases related to heart, pulmonary, renal, metabolic and autoimmune diseases. They were not infected with HCV or HIV. In 102 among 104 pregnant women elevated ALT activity was not demonstrated before pregnancy. In 84 pregnant $(81 \%)$ ultrasound examination was performed within 12 months prior to pregnancy, and no significant abnormalities were found in the liver structure.

After discontinuation of antiviral therapy due to pregnancy, no increase in alanine aminotransferase (ALT) activity (flares) and no abnormalities during pregnancy were observed in two women treated with antivirals before pregnancy. In both women $\mathrm{HBV}$ DNA was undetectable in the third trimester of pregnancy and both newborns were healthy with an Apgar score of 10 points.

Alanine aminotransferase activity was increased 2 fold in 6 out of 104 pregnant women (5.8\%). All patients felt well and no complications were observed during pregnancy.

Two pregnant women had miscarriages in the $12^{\text {th }}$ and $14^{\text {th }}$ weeks of pregnancy. Miscarriages occurred 
Table 1. Characteristics of patients

\begin{tabular}{lc}
\hline Number of all deliveries & 104 \\
\hline Miscarriage, $n(\%)$ & $2 / 104(1.9 \%)$ \\
\hline Newborn deaths, $n(\%)$ & $1 / 104(1 \%)$ \\
\hline Spontaneous labor, $n(\%)$ & $57 / 102(56 \%)$ \\
\hline Caesarean section, $n(\%)$ & $45 / 102(44 \%)$ \\
\hline
\end{tabular}

Table 2. Hepatitis B virus (HBV) DNA viral level in third trimester of pregnancy $(n=59)$

\begin{tabular}{lccc}
\hline HBV DNA (IU/ml) & $\boldsymbol{n}(\%)$ & Mode of delivery & $\boldsymbol{n}(\%)$ \\
\hline$<10^{2}$ & $12(20 \%)$ & Caesarean section & $6(50 \%)$ \\
\cline { 3 - 4 } & & Spontaneous labor & $6(50 \%)$ \\
\hline $10^{2}-10^{3}$ & $16(28 \%)$ & Caesarean section & $8(50 \%)$ \\
\cline { 3 - 4 } & & Spontaneous labor & $8(50 \%)$ \\
\hline $10^{3}-10^{4}$ & $20(34 \%)$ & Caesarean section & $7(35 \%)$ \\
\cline { 3 - 4 } & & Spontaneous labor & $13(65 \%)$ \\
\hline $10^{4}-10^{5}$ & $6(10 \%)$ & Caesarean section & $2(33 \%)$ \\
\cline { 3 - 4 } & & Spontaneous labor & $4(67 \%)$ \\
\hline $10^{5}-10^{6}$ & $5(8 \%)$ & Caesarean section & $2(40 \%)$ \\
\cline { 3 - 4 } & & Spontaneous labor & $3(60 \%)$ \\
\hline
\end{tabular}

suddenly and were preceded by abdominal pain and vaginal bleeding without clear reason. These miscarriages were probably not related to $\mathrm{HBV}$ infection. Moreover, in one case a newborn's death occurred, which was also not connected with HBV infection but was a consequence of staphylococcemia that developed in the postnatal period. The newborn was of the twin pregnancy which was delivered at the $28^{\text {th }}$ week. One hundred three children were followed after birth.

Delivery occurred at a mean time of 37 weeks (from 21 to 42 weeks) of pregnancy. In the case of 45 pregnancies, children were born by caesarean section, while 57 deliveries were spontaneous (Table 1).

We did not find a viral load above 107 in the third trimester of pregnancy in pregnant women surveyed (Table 2).
According to Polish regulations, HBV infection is considered as a relative indication for caesarean section. The decision on the type of delivery is taken by the pregnant woman. In the studied group of patients there were no other medical indications for delivery by cesarean section except HBV infection. Boys were born in 55 cases (53\%) and girls in 49 cases (47\%) (Table 3). Three children developed HBV infection, which was connected with lack of prophylaxis in 2 newborns and incomplete prophylaxis (administration of a vaccine but not specific immunoglobulins) in one case (Table 4).

There was no statistically significant differences between mean Apgar score in girls and boys. In studies carried out previously in the Podlasie Province concerning neonates born to healthy mothers $(n=206)$, the mean Apgar score was 8.98, and there was no statistically significant difference $\left(9.32\right.$ vs. $8.98 ; \chi^{2}=3.796$, $p=0.052)[6]$.

Allergic disorders occurred in 17 children who underwent HBV prophylaxis with the vaccine (2 children) or serum and vaccine (15 children) (Table 5).

\section{Discussion}

Studies on chronic HBV infection in the course of pregnancy have been inconclusive. Tse et al. [7] reported higher risk of diabetes or antenatal hemorrhage in $\mathrm{HBV}$-infected pregnant women. The studies by Wong et al. [8] did not reveal a negative effect of HBV infection on the course of pregnancy. It may be connected with a high concentration of estrogens, endogenous antioxidants, which inhibit liver fibrosis, hepatocyte apoptosis as well as Kupffer cells in the liver [9]. Our own studies did not reveal a negative effect of HBV infection on health condition of pregnant patients, either.

High concentrations of pro-inflammatory cytokines (IL) 2, 6, and 10, macrophage migration inhibitory factor, and TNF- $\alpha$ in HBV-infected pregnant women can lead to an increased percentage of preterm deliveries as well as worse condition of newborns (lower Apgar score) [7]. Our study revealed miscarriage in $2.1 \%$ of pregnant women. On the other hand, $16 \%$ of newborns had an Apgar score below 9. It is assumed that miscarriages in healthy women occur in $13-20 \%$ of cases.

Table 3. Characteristics of neonates born to hepatitis B virus (HBV) infected women

\begin{tabular}{lcccc}
\hline & $n(\%)$ & Birth weight & Number and percentage of births with Apgar score below 9* & Apgar score; mean \pm SE \\
\hline Girls & $49(47 \%)$ & $3261(1400-4600)$ & $5(10 \%)$ & $9.51 \pm 0.25$ \\
\hline Boys & $55(53 \%)$ & $3393(1330-4320)$ & $10(18 \%)$ & $9.24 \pm 0.27$ \\
\hline Total & $104(100 \%)$ & $3274(1330-4600)$ & $15(14 \%)$ & $9.32 \pm 0.18$ \\
\hline
\end{tabular}

*Score 9-10 - newborn in good condition 
Table 4. Prophylaxis of neonates born to hepatitis B virus (HBV)-infected mothers

\begin{tabular}{lcc}
\hline & $n(\%)$ & $\begin{array}{c}\text { HBV infection, } \\
n(\%)\end{array}$ \\
\hline $\begin{array}{l}\text { Newborns who were given sera } \\
\text { and HBV vaccines }\end{array}$ & $81(79 \%)$ & 0 \\
\hline $\begin{array}{l}\text { Newborns who were given } \\
\text { HBV vaccines }\end{array}$ & $17(16 \%)$ & $1(6 \%)$ \\
\hline Newborns without any prophylaxis & $5(5 \%)$ & $2(40 \%)$ \\
\hline All newborns* & $103(100 \%)$ & $3(2.9 \%)$ \\
\hline
\end{tabular}

*Except for one newborn who died in the course of septicemia

The rate of their occurrence decreases together with pregnancy development. After 8 weeks, the rate of miscarriages is assessed as $2-3 \%$ [10]. In the examined group of pregnant women, two miscarriages occurred in the $12^{\text {th }}$ and $14^{\text {th }}$ weeks of pregnancy. Our study concerning miscarriages in $\mathrm{HBV}$-infected pregnant women showed that they were comparable to those without the infection. In the study by Piec et al. [11], a very good condition of newborns (high Apgar score) occurred in $87 \%$ to $95 \%$ of newborns, delivered mostly through natural passages. In the group of 206 newborns born in the Podlasie Province to healthy women, the mean Apgar score was 8.98 , so it was comparable to 9.32 $\left(\chi^{2}=3.796, p=0.052\right)$ observed for children born from HBV infected mothers in our study [6]. In the examined group of newborns, $86 \%$ presented a very good condition according to the Apgar score.

In Europe, approximately $85 \%$ of $\mathrm{HBV}$-infected pregnant women are $\mathrm{HBeAg-negative,} \mathrm{and} \mathrm{this} \mathrm{per-}$ centage is consistent with the general HBV-infected population in pregnancy, a high concentration of adrenal corticosteroids may stimulate increase of $\mathrm{HBV}$ viral load $[1,12]$. In the pre-delivery period, high viral load $\left(10^{7} \mathrm{IU} / \mathrm{ml}\right)$ as well as HBeAg positivity can lead to newborn infection, specifically in the case of spontaneous labor [13]. Our study showed only 5 (8\%) of HBeAg-negative patients with high HBV viral load $\left(>10^{5} \mathrm{IU} / \mathrm{ml}\right.$ ) in the third trimester of pregnancy. In the perinatal period, a significant reactivation of $\mathrm{HBV}$, resulting in severe liver damage accompanying hepatic encephalopathy, can sometimes occur [14]. It is interesting to observe that prophylactic administration of lamivudine in the third trimester of pregnancy prevents newborn infection but does not decrease the risk of liver failure, which can occur due to a significant increase in viral replication [15]. We did not introduce any antivirals during pregnancy, which is line with the proposals by Whittaker and Herrera [16]. None of the women demonstrated a HBV level above $10^{6} \mathrm{IU} / \mathrm{ml}$ in the third trimester of pregnancy. Low viral load in
Table 5. Diseases occurring in 103 children born to HBV-infected mothers. Mean age 5.7 years (from 1 to 13 years)

\begin{tabular}{lccc}
\hline Disease & $\begin{array}{c}\text { Girls } \\
\boldsymbol{n}=48^{*}\end{array}$ & $\begin{array}{c}\text { Boys } \\
\boldsymbol{n}=55\end{array}$ & $\begin{array}{c}\text { Total } \\
\boldsymbol{n}=103\end{array}$ \\
\hline Food allergy & $5(10.4 \%)$ & $5(9.1 \%)$ & $10(9.7 \%)$ \\
\hline Atopic dermatitis & 0 & $5(9.1 \%)$ & $5(4.9 \%)$ \\
\hline Bronchial asthma & 0 & $2(3.6 \%)$ & $2(1.9 \%)$ \\
\hline Lactose intolerance & $2(4.2 \%)$ & $1(1.8 \%)$ & $3(2.9 \%)$ \\
\hline Diabetes & 0 & $2(3.6 \%)$ & $2(1.9 \%)$ \\
\hline $\begin{array}{l}\text { Pyelocaliectasis of both } \\
\text { kidneys }\end{array}$ & $1(2.1 \%)$ & 0 & $1(0.9 \%)$ \\
\hline Total & $8(16.7 \%)$ & $15(27.2 \%)$ & $23(22.3 \%)$ \\
\hline
\end{tabular}

*Except for the girl who died in the course of septicemia

HBeAg negative patients predicts lower probability of newborn infection in the perinatal period in the case of spontaneous labor.

All deliveries by cesarean section were scheduled and none were carried out urgently. According to Zou and Chen [17], the likelihood of neonatal HBV infection is lower after planned surgical intervention compared to the need of urgent caesarean section.

We did not observe newborn HBV infection in the case of proper complete prevention. This observation is consistent with the conclusion from the study by Gentile and Borgia [18]. Children born to mothers with HBV should obtain the specific immunoglobulin and the first dose of anti-HBV vaccine in the first 24 hours. It is disturbing to observe that the specific serum was not administered in $16 \%$ of cases and 5 newborns (5\%) did not undergo prevention at all. Proper prevention protects a newborn against infection at labor and in the postnatal period as well as protecting breastfeeding [19].

None of the children showed congenital disorders. The frequency of allergy in children aged from 0 to 14 years is estimated as $13.7 \%$ in girls and $18.3 \%$ in boys in Poland [20]. Immunoglobulins E (IgE) play the most important role in allergic reactions, and the gene that controls their excessive production is inherited and located on the fifth chromosome. It can be activated by various external factors, usually proteins in food, grass pollen, mould spores, fur, and drugs [21, 22]. We think that probably these factors affect the common allergic reactions of newborns.

\section{Conclusions}

Low viral load in HBV-infected HBeAg-negative women is associated with minimal risk of newborn infection. Measurement of HBV viral load in the third 
trimester of pregnancy may have a significant effect on the mode of delivery. Postnatal anti-HBV prevention plays a crucial role in the protection of newborns against HBV infection and possible serious consequences such as liver cirrhosis and hepatocellular carcinoma.

\section{Disclosure}

The authors report no conflict of interest.

\section{References}

1. Jonas MM. Hepatitis B and pregnancy: an underestimated issue. Liver International 2009; 29 Suppl 1: 133-139.

2. Towers CV, Asrat T, Rumney P. The presence of hepatitis B surface antigen and deoxyribonucleic acid in amniotic fluid and cord blood. Am J Obstet Gynecol 2001; 184: 1514-1518.

3. Aniszewska M, Kowalik-Mikołajewska B, Pokorska-Lis M. Mother-to-child transmitted HBV infection in a girl without full perinatal prophylaxis - course and therapeutic diffi culties. Exp Clin Hep 2007; 2: AB10-10.

4. Yang X, Cui MX, Liu BG. Breast-feeding by mothers with positive serum hepatitis B virus test. Zhonghua Fu Chan Ke Za Zhi 1994; 29: 586-588, 635.

5. Li-Na M, Xiang-Chun D, Xiao-Yan L, et al. De novo combination therapy adefovir plus lamivudine as a treatment for women of child-bearing age with $\mathrm{HBeAg}$-positive chronic hepatitis B Before Pregnancy. J Med Virol 2014; 86: 433-436.

6. Golonko B. Analiza epidemiologiczna przyczyn umieralności okołoporodowej na terenie województwa podlaskiego w latach 2000-2007. Rozprawa doktorska, Białystok 2009; 83.

7. Tse KY, Ho LF, Lao T. The impact of maternal HBsAg carrier status on pregnancy outcomes: a case-control study. J Hepatol 2005; 43: 771-775.

8. Wong S, Chan LY, Yu V, Ho L. Hepatitis B carrier and perinatal outcome in singleton pregnancy. Am J Perinatol 1999; 16: 485488.

9. Shimizu I, Kohno N, Tamaki K, et al. Female hepatology: favorable role of estrogen in chronic liver disease with hepatitis B virus infection. World J Gastroenterol 2007; 13: 4295-4305.

10. Kutteh WH. Recurrent pregnancy loss, in precis, an update in obstetrics and gynecology. $2^{\text {nd }}$ ed. American College of Obstetrics and Gynecology, Washington 2002; 151-161.

11. Piec P, Suchocki S, Obst M, et al. Ocena stanu noworodka urodzonego cięciem cesarskim w porównaniu z porodem drogą pochwową. Perinatologia, Neonatologia i Ginekologia 2008; 1: 94-97.

12. Chou CK, Wang LH, Lin HM, Chi CW. Glucocorticoid stimulates hepatitis B viral gene expression in cultured human hepatoma cells. Hepatology 1992; 16: 13-18.

13. Dwivedi M, Misra SP, Misra V, et al. Seroprevalence of hepatitis B infection during pregnancy and risk of perinatal transmission. Indian J Gastroenterol 2011; 30: 66-71.

14. Yang YB, Li XM, Shi ZJ, Ma L. Pregnant woman with fulminant hepatic failure caused by hepatitis B virus infection: a case report. World J Gastroenterol 2004; 10: 2305-2306.

15. ter Borg MJ, Leemans WF, de Man RA, Janssen HL. Exacerbation of chronic hepatitis B infection after delivery. J Vir Hepat 2008; 15: 37-41.

16. Whittaker G, Herrera JL. Hepatitis B in pregnancy. South Med J 2014; 107: 195-200.

17. Zou H, Chen Y, Duan Z, et al. A retrospective study for clinical outcome of caesarean section on perinatal transmission of hep- atitis $B$ virus in infants born to $\mathrm{HBeAg}$ positive mothers with chronic hepatitis B (CHB). Presented at: $61^{\text {st }}$ Annual Meeting of the American Association for the Study of Liver Disease. Abstract 235, Boston, MA, USA.

18. Gentile I, Borgia G. Vertical transmission of hepatitis B virus: challenges and solutions. Int J Womens Health 2014; 6: 605-611.

19. Shi Z, Yang Y, Wang H, et al. Breastfeeding of newborns by mothers carrying hepatitis B virus: a meta-analysis and systematic review. Arch Pediatr Adolesc Med 2011; 165: 837-846.

20. Falkowska E, Telusiewicz-Pacak A. Dzieci w Polsce, dane, liczby, statystyki. PKN, UNICEF, Warszawa 2013.

21. Owczarek-Lipska M, Lauber B, Molitor V, et al. Two loci on chromosome 5 are associated with serum IgE levels in Labrador retrievers. PLoS One 2012; 7: e39176.

22. Cakir M, Karakas T, Orhan F, et al. Atopy in children with chronic hepatitis B virus infection. Acta Paediatr 2007; 96: 1343-1346. 